DOI: $10.17957 / \mathrm{JJAB} / 15.1881$

http://www.fspublishers.org

\title{
Chemical Investigations on Algerian Mentha rotundifolia and Myrtus communis Essential Oils and Assessment of their Insecticidal and Antifungal Activities
}

\author{
Ghozlene Aouadi $^{*}$, Abir Soltani², Leila Kalai Grami², Maha Ben Abada', Soumaya Haouel², Emna Boushih², Manel \\ Chaanbi $^{2}$, Salem Elkahoui ${ }^{3}$, Mohamed Rabeh Hajlaoui ${ }^{2}$, Jouda Mediouni Ben Jemâa ${ }^{2}$ and Faiza Taibi ${ }^{1,4}$ \\ ${ }^{1}$ Laboratoire de Biodiversité et Pollution des Écosystèmes, Université Chadli Bendjedid, Bp 76, El-Tarf, Algérie \\ ${ }^{2}$ Laboratoire de Biotechnologie Appliquée à l'Agriculture, INRAT, Université de Carthage, Rue HediKarray, 1004 El \\ Menzah, Tunis, Tunisie \\ ${ }^{3}$ Department of Biology, College of Science, University of Ha'il, PO Box 2440, 81451, Kingdom of Saudi Arabia \\ ${ }^{4}$ Laboratoire de Biologie Animale appliquée, Département de Biologie, Faculté des Sciences, Université Badji Mokhtar, Bp \\ 12, Annaba, Algérie \\ For correspondence: ghozleneaouadi@yahoo.fr \\ Received 05 February 2021; Accepted 11 September 2021; Published 15 December 2021
}

\begin{abstract}
This work aimed to assess in vitro insecticidal and antifungal activities of Mentha rotundifolia and Myrtus communis essential oils against the red flour beetle (Tribolium castaneum) and three fungal species (Botrytis cinerea, Fusarium solani and Colletotrichum acutatum). Oxygenated monoterpenes presented the dominant group with 72.94 and $58.92 \%$ respectively for M. rotundifolia and $M$. communis essential oils. $M$. rotundifolia and $M$. communis essential oils composition was dominated by 72.94 and $58.92 \%$ of oxygenated monoterpenes, respectively. The determined lethal concentrations of mentha essential oils against $T$. castaneum adults revealed high toxicity respectively for fumigant and contact tests, $\mathrm{LC}_{50}=0.113 \mu \mathrm{L} \mathrm{cm}^{-2}$ and $\mathrm{LC}_{50}=$ $32.71 \mu \mathrm{L} \mathrm{L}^{-1}$ air. However, common myrtle oil showed a weak fumigant activity ( $\mathrm{LC}_{50}=357.67 \mu \mathrm{L} \mathrm{L}^{-1}$ air) and no contact toxicity. Furthermore, $M$. rotundifolia essential oil showed a marked antifungal toxicity against all the fungal strains. The mycelial growth of the three fungal strains was completely inhibited at the concentrations of $0.33 \mu \mathrm{L} \mathrm{L}^{-1}$ by contact application and 8,10 and $12 \mu \mathrm{L}$ by fumigant application. $M$. communis essential oil displayed only a contact antifungal toxicity against $B$. cinerea at the concentration $21.33 \mu \mathrm{L} \mathrm{L} \mathrm{L}^{-1}$. Additionally, $M$. rotundifolia completely inhibited conidial germination of $B$. cinerea and F. solani, and significantly affected their morphology, with morphological modifications at the rate of 92.94 and $51.11 \%$ respectively. In light of in vitro tests results, the mentha essential oil appeared to be an excellent source of antifungal and insecticidal components and will allow the potential development of this species in the biological control of several pests and fungal diseases. (C) 2021 Friends Science Publishers
\end{abstract}

Key words: Biocontrol; Conidia germination; Mycelial growth inhibition; Rot molds; Tribolium castaneum

\section{Introduction}

Plant pathogens and insect pests pose a serious threat to crops and harvested products, leading to marked yield losses in the field and during storage (Chandrasekaran et al. 2016). Pests of stored products are a chronic problem because they contaminate and depreciate the quality of stored food products (Bande-Borujeni et al. 2018). In developing countries, there is up to $50 \%$ fruit loss during storage and transport and about $35 \%$ of crops are lost annually because of fungi and insect pests (Nunes 2012). The insect Tribolium castaneum (Coleoptera: Tenebrionidae), and the pathogens Botrytis cinerea, Colletotrichum acutatum and Fusarium solani are among the best examples of the most widespread and devastating pests of stored products (Pimentel et al. 2007; Dean et al. 2012). The severity of $T$. castaneum is related to its high multiplication rate coupled with a short life cycle (20 days) under favorable conditions (Kumar et al. 2011). In addition to corpses and wastes, adults contaminate and decrease grain quality by secreting a pungent gas from the thoracic and abdominal glands (Salem et al. 2018).

B. cinerea, $C$. acutatum and $F$. solani are associated with diseases in important economical crops. B. cinerea, the causal agent of the grey mould is known as a polyphagous and a high-risk pathogen due to its large resistance to antibotrytis fungicides (Elad et al. 2016). Owing to its great genotypic and phenotypic variability and its adaptability to

To cite this paper: Aouadi G, A Soltani, LK Grami, MB Abada, S Haouel, E Boushih, M Chaanbi, S Elkahoui, MR Hajlaoui, JMB Jemâa, F Taibi (2021). Chemical investigations on Algerian Mentha rotundifolia and Myrtus communis essential oils and assessment of their insecticidal and antifungal activities. Intl J Agric Biol 26:667-680 
various environments (Júnior et al. 2014), it is classified as the second most important phytopathogenic fungus in the world (Dean et al. 2012). It can even develop successfully over long periods just above the freezing temperatures on cold-stored fruits (Williamson et al. 2007). C. acutatum have been ranked eighth most important pathogen in the world according to Dean et al. (2012). It causes anthracnoses in plants in the form of very damaging black spots, especially when they affect the fruits. This fungus has a wide host range of great economic importance such as strawberry, avocado, citrus, almond, mango and olive. $F$. solani is a soil fungus and parasite of plant species; it is a complex of at least twenty six filamentous fungi associated with numerous diseases on economically important plants. Contamination by fungal diseases decreases the post-harvest storage life and declines the market quality of fruits (Tripathi et al. 2007).

Recently, growing public concern regarding the adverse effects of pesticides and possible damage to the environment and human health has led to increasing attention being given to natural products to control pests (Ali et al. 2020; Khan et al. 2020). Currently, pests control strategies tend to emphasize the non-chemical aspects of pest control (Titouhi et al. 2017; Banaras et al. 2020, 2021; Javed et al. 2021). Essential oils are complex mixtures of volatile compounds, principally monoterpenoids, sesquiterpenoids and phenylpropanoids (Fujita and Kubo 2004), distributed at a quite different concentrations. The bioactivity of essential oils is drastically related to their chemical composition (Zapata and Smagghe 2010), which differs widely within the same species according to the seasonal variations, geographic areas, climatic and edaphic conditions, type of material and methods used for analysis (Salehi et al. 2018). Insect and herbivore attack's is among the causes that push aromatic plants to synthesize them (Bakkali et al. 2008). In recent years, essential oils have been widely selected for their interesting biological applications as insecticides, bactericides, and fungicides (Rahali et al. 2017; Cheraif et al. 2020).

Mentha rotundifolia L. (Lamiaceae) and Myrtus communis L. (Myrtaceae) are the two aromatic plants widely distributed in the north of Algeria. Decoction and infusion of their leaves are used in traditional Algerian medicines to treat several diseases such as hypertension, diabetes, disorders of the digestive and genitourinary system (Boudjelal et al. 2013; Brahmi et al. 2016). The biological activities of the round-leaved mint and common myrtle essential oils such as antioxidant (Benabdallah et al. 2018), antibacterial (Riahi et al. 2013), insecticidal (Aouadi et al. 2020; Kharoubi et al. 2020) and antifungal (Leblalta et al. 2020) have been little described in the literature. In order to develop a new generation of botanical pesticide from natural products, the effectiveness of the fumigant and contact potential of the Algerian M. rotundifolia and M. communis essential oils was evaluated in vitro on virulent strains of $T$. castaneum, B. cinerea, C. acutatum and F. solani.

\section{Materials and Methods}

\section{Plant material}

Fresh leaves of $M$. communis and $M$. rotundifolia were harvested respectively in October 2017 and August 2018 from two different areas of Annaba region (M. communis from Ain Barbar: $36^{\circ} 55^{\prime} \mathrm{N}, 7^{\circ} 36^{\prime} \mathrm{E}$ and $M$. rotundifolia from Berrahel: $36^{\circ} 50^{\prime} \mathrm{N}, 7^{\circ} 27^{\prime} \mathrm{E}$ ) both situated in Northeastern Algeria. The collected samples were air-dried in shadow at room temperature $\left(20-25^{\circ} \mathrm{C}\right)$ for a week and then stored in glass boxes for further use.

\section{Extraction of the essential oils}

Essential oils of each species were extracted from dried leaves (100 g) using Clevenger apparatus during $90 \mathrm{~min}$. Essential oils were stored in amber flasks and tightly closed at $4^{\circ} \mathrm{C}$. Essential oils' yields were calculated according to dry weight of the plant materials (Afnor 1986).

\section{Gas chromatography - mass Spectrometry (GC/MS) analysis}

Essential oils were analyzed using an Agilent 7890A gas chromatograph coupled to an Agilent 5972C mass spectrometer with electron impact ionization $(70 \mathrm{eV})$. The mass spectrometer was equipped with a capillary column HP-5 MS (19091S-433), length $30 \mathrm{~m}$, diameter $250 \mu \mathrm{m}$ and $2.5 \mu \mathrm{m}$ film thicknesses (5\% phenyl methyl silicone, $95 \%$ dimethylpolysiloxane; Hewlett-Packard, CA, USA). The column temperature was programmed to rise from $50^{\circ} \mathrm{C}$ to $250^{\circ} \mathrm{C}$ at a rate of $7^{\circ} \mathrm{C} / \mathrm{min}$. The flow rate of carrier gas (Helium) was $1 \mathrm{~mL} / \mathrm{min}$. A sample of $2 \mu \mathrm{L}$ was manually injected with a constant pressure of 7.65 psi using split mode (split ratio 1:50). The identification of essential oils components was established by comparing their retention indices (RI) to n-alkanes with those published in literature or matching them to spectra of authentic compounds recorded in Wiley Registry 9 $^{\text {th }}$ Edition/NIST 2011 edition mass spectral library.

\section{Insecticidal activities}

Insect rearing: $T$. castaneum adults were obtained from rearing colonies kept at darkness on wheat flour and semolina in $2 \mathrm{~L}$ plastic storage boxes at $25 \pm 1^{\circ} \mathrm{C}$ and $65 \pm$ $5 \%$ relative humidity. Adult's insects 7-14 days old were used for all bioassays.

Fumigant toxicity: To assess fumigant toxicity of $M$. communis and $M$. rotundifolia essential oils and the exposure time required to kill $50 \%$ of the insects, ten adults of $T$. castaneum were placed in Plexiglas flasks of $38 \mathrm{~mL}$ volume according to Haouel et al. (2010). The bottom surface of the screw caps was lined with Whatman no. 1 filter paper discs $(2 \mathrm{~cm}$ diameter with a $3 \mathrm{~cm}$ length fixing 
tab). Using a micro-pipette, filter paper discs were imbued with different essential oils doses of $2.5,5,7.5$ and $10 \mu \mathrm{L}$ (without any solvent) corresponding to the following concentrations of $65.8,131.6,197.36$ and $263.15 \mu \mathrm{L} \mathrm{L}^{-1}$ air. Filter papers were hanged up to the screw caps and were quickly screwed tightly onto the bottles. Control and all concentrations were replicated three times and kept in similar conditions. Insects' mortality was recorded each hour by direct observation. When no antenna or leg movements were detected, insects were considered as dead. The Abbott correction formula (Abott 1925) was used to calculate the percentage of mortality. Lethal concentrations $\mathrm{LC}_{50}$ and $\mathrm{LC}_{95}$ and lethal time $\mathrm{LT}_{50}$ values were estimated by using Probit analysis (IBM SPSS v. 22).

Contact toxicity: Filter paper contact method was used in order to evaluate contact toxicity of $M$. communis and $M$. rotundifolia essential oils according to Zhang et al. (2018) with slights modifications. A Whatman (No.1) filter paper discs $(9 \mathrm{~cm} \varnothing)$ were soaked with a series of essential oil dilutions dissolved in acetone to obtain concentration range of $0.07,0.11$ and $0.15 \mu \mathrm{L} \mathrm{cm} \mathrm{cm}^{-2}$. Acetone was used as negative control. After five minevaporation of acetone at room temperature, each disc was then putted in a glass Petri dish and 10 adults of $T$. castaneum were placed in it. Control and each concentration have been replicated three times. The number of dead insects was registered until total insect's elimination. The mortality percentage was corrected using Abbott's formula. Probit analysis (IBM SPSS v. 22) was used to calculate $\mathrm{LC}_{50}, \mathrm{LC}_{95}$ and $\mathrm{LT}_{50}, \mathrm{LT}_{95}$ values.

\section{Anti-fungal activity}

Fungal strains, culture and storage: Strains of Fusarium solani, Botrytis cinerea and Colletotrichum acutatum were provided from the Laboratory of Biotechnology Applied to Agriculture, INRAT, Tunis. Cultures of micro-organisms were maintained on potato dextrose agar (PDA) medium at $24 \pm 2^{\circ} \mathrm{C}$ for $7-14$ days.

Toxic medium method: The antifungal toxicity of $M$. rotundifolia and $M$. communis essential oils against $F$. solani, $C$. acutatum and B. cinerea was evaluated according to the method of Regnier et al. (2008) with slight modifications. It consists in incorporating essential oil into $15 \mathrm{~mL}$ of sterile Potato Dextroseagar media (PDA) and homogenizing the mixture before pouring in Petri dishes. Thereafter, mycelial growth of $8 \mathrm{~mm}$ fugal discs recovered from seven days old cultures, was evaluated on PDA essential oil mixture during 5 days at $25^{\circ} \mathrm{C}$.

The effectiveness of both essential oils was firstly screened at $21.33 \mu \mathrm{L} \mathrm{mL}-1$ and then eight increasing concentrations of the most efficient oil $(0.08,0.16,0.33$, $0.66,1.33,2.66,5.33$ and $10.66 \mu \mathrm{L} \mathrm{mL}^{-1}$ ) were similarly tested. Minimum inhibitory concentration was determined solely for the oil having the broadest antifungal spectrum.
Three repetitions were performed for each essential oil and each concentration. The growth inhibition was calculated according to the formula of Cakir et al. (2005), in percentage inhibition of the radial growth of the treated samples compared to the control.

$$
\% \text { inhibition }=(\mathrm{C}-\mathrm{T}) / \mathrm{C} \times 100
$$

Where $\mathrm{C}=$ average of mycelial growth of controls, $\mathrm{T}=$ average of mycelial growth of treated samples.

The lowest concentration that shows no fungal growth observable to the naked eye was considered as minimum inhibitory concentration (MIC).

Volatile activity method: The effect of essential oil vapors against the tested strains was also estimated using the volatile activity technique as described by Neri et al. (2006) with slights modifications. The efficiency of essential oils was first evaluated at a fixed dose $12 \mu \mathrm{L}$. Thereafter, the minimum inhibitory concentrations were determined solely for fungal strains whose mycelial growth was completely inhibited by essential oils vapors.

For this test, an $8 \mathrm{~mm}(\varnothing)$ agar disc recovered from seven day old culture was inoculated into PDA petri dishes (90 $\mathrm{mm}$ ) and exposed to volatile substances. Essential oil vapors were provided by squares of Whatman filter paper (No. 1) soaked with $(6,8,10 \mu \mathrm{L})$ crude essential oils and glued to the underside of Petri dishes lids. Petri dishes were hermetically sealed with Parafilm, inverted and then incubated for 5 days in the dark at $25 \pm 2{ }^{\circ} \mathrm{C}$. Three repetitions were performed for each concentration and each oil. Mycelium growth diameters were noted daily and data were expressed as percentage inhibition of the radial mycelial growth (Plaza et al. 2004). The minimum inhibitory concentration (MIC) was determined for the oil having the broadest antifungal spectrum and is assigned to the lowest concentration able to completely inhibiting fungal growth.

Minimal fungicidal concentration (MFC): For both of the above methods, minimal fungicidal concentration (MFC), was determined solely for the oil having the broadest antifungal spectrum by transferring and re-inoculating in fresh PDA medium mycelial disks which showed no visual growth. Fungal development was monitored after 7 days incubation in the dark at $24^{\circ} \mathrm{C}$.

Spores germination: Spore germination assay was conducted solely for fungi completely inhibited by essential oils. Fungal conidial suspension was prepared by collecting conidia from ten days old culture resuspended in 5\% sterile glucose solution and adjusted by hemocytometer (Malassez) to $10^{5}$ spores $/ \mathrm{mL}$. In vitro assays were performed using concave micro-culture slides by mixing $40 \mu \mathrm{L}$ of each crude essential oil with $40 \mu \mathrm{L}$ of conidial suspension $\left(10^{5}\right.$ cells $\left.\mathrm{mL}^{-1}\right)$. Control was prepared by mixing $40 \mu \mathrm{L}$ of sterile glucose solution $(5 \%)$ with $40 \mu \mathrm{L}$ of conidial suspension $\left(10^{5}\right.$ cells $\left.\mathrm{mL}^{-1}\right)$. Slides were incubated in a wet, dark 
chamber at $25^{\circ} \mathrm{C}$ for $48 \mathrm{~h}$ and then observed with an optical microscope (Leica) at 1000 magnification. Each treatment was conducted in quadruplicate. The percentage of conidial germination was evaluated using four regions per slide corresponding to at least 300 conidia.

\section{Data analysis}

Results were analyzed by one-way ANOVA followed by Duncan test to perceive significant differences at the $P \leq$ 0.05. All data were expressed as the mean of three replication \pm standard deviation $(\overline{\mathrm{x}} \pm \mathrm{SD})$. All statistical analyses were accomplished using IBM SPSS v. 22.

\section{Results}

\section{Chemical composition}

The essential oil yields for $M$. communis and $M$. rotundifolia were 0.64 and $1.29 \%$ respectively (Table 1). The chemical analyses enabled the identification of twenty volatile compounds amounting $95.13 \%$ in $M$. communis oil and thirty constituents in $M$. rotundifolia oil corresponding to $95.51 \%$. Table 1 depicted the identified components ordered into several chemical classes, their percentages and their retention index (RI). Results showed that $M$. communis was dominated by 1,8 cineole $(36.82 \%)$ and $\alpha$-pinene (29.08\%). Nevertheless, the major compounds recognized in $M$. rotundifolia were rotundifolone $(46.06 \%)$ and Dlimonene $(9.10 \%)$. As can be seen, oxygenated monoterpenes class represented the major fraction of both essential oils: $M$. rotundifolia $(72.94 \%)$ and $M$. communis $(58.92 \%)$ followed by monoterpene hydrocarbons class which represents $35.25 \%$. for $M$. communis and $17.74 \%$ for M. rotundifolia.

\section{Fumigant toxicity}

As showed in Fig. 1, M. rotundifolia exhibited high fumigant toxicity against $T$. castaneum adults comparatively to $M$. communis oil $\left(\mathrm{F}_{1,96}=2180.06, P \leq 0.001\right)$. Results of adult's mortality showed a dose - response relationship with oils concentrations. In fact, mortality increased significantly with increasing essential oil concentrations $\left(\mathrm{F}_{3,96}=86.72, P\right.$ $\leq 0.001)$ and exposure time $\left(\mathrm{F}_{5,96}=269.32, P \leq 0.001\right)$. For $M$. rotundifolia, the lowest concentration $\left(65.8 \mu \mathrm{L} \mathrm{L}^{-1}\right.$ air $)$ induced complete mortality after 30 hours of exposure time whereas no mortality was registered in the same conditions with M. communis oil. After exposition of $24 \mathrm{~h}$ at the concentration of $131.6 \mu \mathrm{L} \mathrm{L}^{-1}$ air, $M$. communis oil caused only $3.33 \%$ mortality compared to $100 \%$ mortality with $M$. rotundifolia. Moreover, at the highest concentration (263.15 $\mu \mathrm{L} \mathrm{L}^{-1}$ air), mortality of $T$. castaneum adults attained $20 \%$ and $100 \%$ for $M$. communis, and $M$. rotundifolia respectively after $18 \mathrm{~h}$ of exposure. Additionally, Probit analyses demonstrated that $T$. castaneum was more sensitive to the round leaf mint essential oil. $\mathrm{LC}_{50}$ and $\mathrm{LC}_{95}$ values were correspondingly to $32.71 \mu \mathrm{L} \mathrm{L}^{-1}$ air and $218.14 \mu \mathrm{L} \mathrm{L}^{-1}$ air at $18 \mathrm{~h}$ comparatively to $357.67 \mu \mathrm{L} \mathrm{L}^{-1}$ air and $530.69 \mu \mathrm{L}$ $\mathrm{L}^{-1}$ air for common myrtle oil (Table 2). Likewise, $\mathrm{LT}_{50}$ and $\mathrm{LT}_{95}$ values confirmed that round leaf mint oil was more toxic than oil of common myrtle (Table 3). $\mathrm{LT}_{50}$ and $\mathrm{LT}_{95}$ values went from $13.2 \mathrm{~h}$ to $17.98 \mathrm{~h}$ and $15.6 \mathrm{~h}$ to $23.78 \mathrm{~h}$ for round leaf mint and from $37.82 \mathrm{~h}$ to $97.94 \mathrm{~h}$ and $84.17 \mathrm{~h}$ to $161.6 \mathrm{~h}$ for common myrtle. In the current study, data indicated that $M$. rotundifolia and $M$. communis essential oils expressed fumigant activity against $T$. castaneum, however $M$. rotundifolia was the most effective. $T$. castaneum adults were about six times more susceptible to the fumigant toxicity of $M$. rotundifolia than M. communis essential oils.

\section{Contact toxicity}

Results of contact test against $T$. castaneum were reported in Table 4 as percentage mortality $( \pm$ S.E). Statistical analysis showed very high significant differences in mortality as function as plant species $\left(\mathrm{F}_{1,72}=8949.16, P \leq 0.001\right)$. Indeed, $M$. communis oil did not lead to any mortality with any tested concentrations contrary to $M$. rotundifolia which caused complete elimination of $T$. castaneum adults after 48 $\mathrm{h}$ of exposure to $0.15 \mu \mathrm{L} \mathrm{cm} \mathrm{cm}^{-2}$ concentration (Table 4). Furthermore, the toxicity of $M$. rotundifolia oil varied significantly according to concentration $\left(\mathrm{F}_{2,72}=55.96, P \leq\right.$ $0.001)$, exposure time $\left(\mathrm{F}_{5,72}=40.36, P \leq 0.001\right)$ and their interaction $\left(\mathrm{F}_{10,72}=7.76, P \leq 0.001\right)$. Probit analysis revealed the high potential of contact toxicity of $M$. rotundifolia against $T$. castaneum. Table 5 displays $\mathrm{LC}_{50}$ and $\mathrm{LC}_{95}$ values of $M$. rotundifolia essential oils against $T$. castaneum adults. The concentration for the essential oil to cause 50 and $95 \%$ mortality $\left(\mathrm{LC}_{50}\right)$ and $\left(\mathrm{LC}_{95}\right)$ in $T$. castaneum was $0.113 \mu \mathrm{L} \mathrm{cm}^{-2}$ and $0.164 \mu \mathrm{L} \mathrm{cm} \mathrm{cm}^{-2}$. Table 6 revealed that $\mathrm{LT}_{50}$ values ranged from $12.93 \mathrm{~h}$ and $23.18 \mathrm{~h}$ for the highest concentration $\left(0.15 \mu \mathrm{L} \mathrm{cm}^{-2}\right)$ to $37.14 \mathrm{~h}$ and $63.29 \mathrm{~h}$ for the lowest concentration $\left(0.07 \mu \mathrm{L} \mathrm{cm}^{-2}\right)$.

\section{Fungicidal activity by toxic medium method}

Statistical analyses revealed that growth inhibition of $F$. solani, B. cinerea and C. acutatum induced by $21.33 \mu \mathrm{L}$ $\mathrm{mL}^{-1}$ of $M$. rotundifolia and $M$. communis essential oils varied significantly according to the essential oil $\left(\mathrm{F}_{1,12}=\right.$ 541.12, $P<0.001)$ and the fungus $\left(\mathrm{F}_{2,12}=139.15, P \leq\right.$ $0.001)$. Screening of antifungal activity by contact with essential oils revealed the efficiency of $M$. rotundifolia essential oil compared to $M$. communis (Fig. 2). In fact, mycelial growth of all fungal strains was $100 \%$ inhibited by $M$. rotundifolia oil while, $M$. communis essential oil did not inhibit all fungus equally as it inhibited $100 \% \mathrm{~B}$. cinerea, $49.96 \%$ F. solani and $39.13 \%$ C. acutatum (Fig. 2).

Statistical analyses indicated that the effect of fungus is not significant when studying the activity of different 
Plant Extracts for the Pest Management of Stored Products / Intl J Agric Biol, Vol 26, No 6, 2021

Table 1: Major compounds of M. communis and M. rotundifolia essential oils obtained from leaves sampled from Annaba (Algeria)

\begin{tabular}{|c|c|c|c|c|}
\hline \multirow{2}{*}{\multicolumn{3}{|c|}{$\begin{array}{l}\text { Compounds } \\
\text { Monoterpene hydrocarbons }\end{array}$}} & M. communis & M. rotundifolia \\
\hline & & & 35.25 & 17.74 \\
\hline 1 & $\alpha$-Pinene & 939 & 29.08 & 2.61 \\
\hline 2 & $\beta$-Pinene & 980 & 0.77 & 2.04 \\
\hline 3 & D-Limonene & 1028 & - & 9.10 \\
\hline \multicolumn{3}{|c|}{ Oxygenated monoterpenes } & 58.92 & 72.94 \\
\hline 4 & 1.8-Cineole & 1033 & 36.82 & 0.45 \\
\hline 5 & $\beta$-Linalool & 1098 & 4.04 & - \\
\hline 6 & Endo-borneol & 1165 & - & 4.64 \\
\hline 7 & $\alpha$-Terpineol & 1189 & 6.42 & 0.82 \\
\hline 8 & cis-piperitone oxide & 1261 & - & 6,81 \\
\hline 9 & Rotundifolone & 1376 & - & 46.06 \\
\hline 10 & Geranyl acetate & 1383 & 4.38 & - \\
\hline 11 & cis-jasmone & 1394 & - & 2.47 \\
\hline 12 & Methyl eugenol & 1401 & 2.59 & - \\
\hline \multicolumn{3}{|c|}{ Sesquiterpene hydrocarbons } & 0.42 & 9.35 \\
\hline 13 & Caryophyllene & 1420 & 0.42 & 3.18 \\
\hline 14 & GermacreneD & 1485 & - & 3,58 \\
\hline \multicolumn{3}{|c|}{ Oxygenated sesquiterpenes } & 0.96 & 0.87 \\
\hline \multicolumn{3}{|c|}{ Other } & & 3.96 \\
\hline \multirow{2}{*}{\multicolumn{3}{|c|}{ Total identified (\%) }} & 95.13 & 95.51 \\
\hline & & & 0.64 & 1.29 \\
\hline
\end{tabular}

-: compound not detected; RI: Retention Index calculated on a HP-5MS capillary column (30 m x $0.25 \mathrm{~mm}$ x $0.25 \mathrm{~mm})$
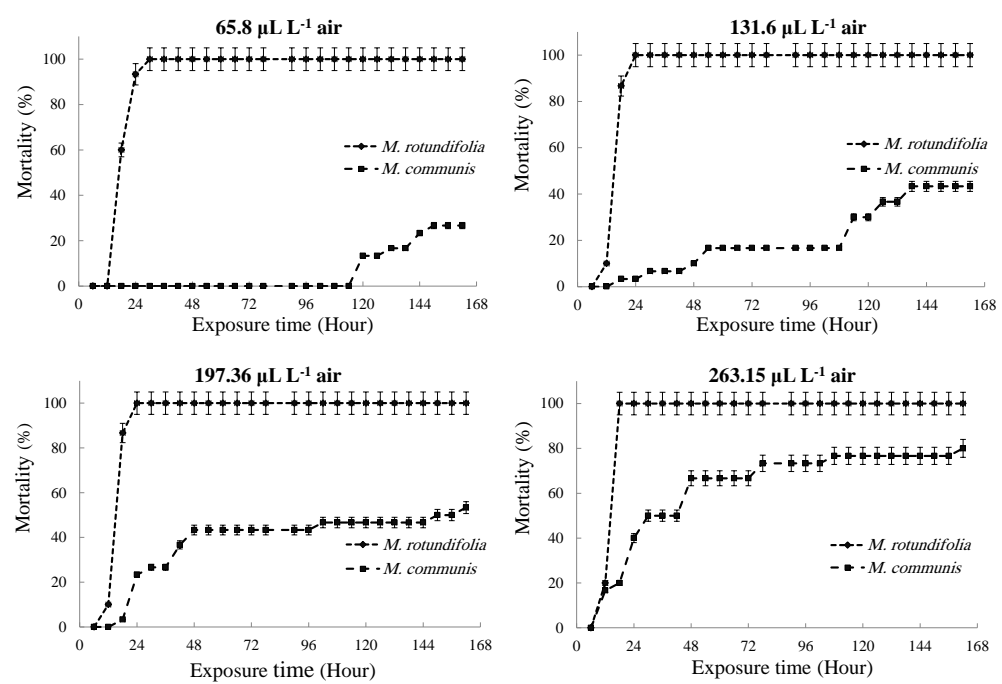

Fig. 1: Mortality (\%) of Tribolium castaneum adults exposed for various periods of time and various concentrations to Mentha rotundifolia and Myrtus communis. essential oils

concentration of $M$. rotundifolia oil on mycelial growth of $B$. cinerea, $F$. solani and $C$. acutatum. Indeed, there was no significant difference in the inhibition percentage of mycelial growth between the fungal strains treated with $M$. rotundifolia oil $\left(\mathrm{F}_{2,48}=3.27, P>0.05\right)$ (Fig. 3). At the concentration $0.08 \mu \mathrm{L} \mathrm{mL}-1$, inhibition percentage had reached $43.33,52.77$ and $69.26 \%$ for $F$. solani, $B$. cinerea and $C$. acutatum respectively. Nevertheless, increasing concentrations of $M$. rotundifolia oil resulted in a significant increase in the percentage of inhibition of the tested strains $\left(\mathrm{F}_{7,48}=56.41, P<0.001\right)$. Starting from $0.33 \mu \mathrm{L} \mathrm{mL}^{-1}$ of $M$. rotundifolia essential oil, growth of all fungal strain is completely inhibited (Fig. 3 and 4). Consequently, the concentration $0.33 \mu \mathrm{L} \mathrm{mL} \mathrm{mL}^{-1}$ represented the minimum inhibitory concentration (MIC) of the round leaf mint essential oil against fungal strains (Table 7).

\section{Fungicidal activity by volatile activity method}

Statistical analysis showed significant differences in mycelial growth between essential oil treatments $\left(F_{1,12}=\right.$ 9560.27, $P \leq 0.001)$ and between different fungal strains $\left(\mathrm{F}_{2,12}=656.79, P \leq 0.001\right)$. Data showed that $M$. rotundifolia oil inhibited $100 \%$ mycelial growth of all tested fungi at 12 $\mu \mathrm{L}$. However, the fumigation of fugal strains with $12 \mu \mathrm{L}$ of $M$. communis oil was totally inefficient towards $B$. cinerea and inhibited 47.4 and $55.19 \%$ the growth of $C$. acutatum and F. solani respectively (Fig. 5). According to these 
Table 2: $\mathrm{LC}_{50}$ and $\mathrm{LC}_{95}$ of Mentha rotundifolia and Myrtus communis essential oils applied by fumigation against Tribolium castaneum

\begin{tabular}{|c|c|c|c|c|c|c|}
\hline Essential oils & $\begin{array}{l}\mathrm{LC}_{50}(\mathrm{a}, \mathrm{b}) \\
\left(\mu \mathrm{LL}^{-1} \text { air }\right)\end{array}$ & $\begin{array}{l}\mathrm{LC}_{95}(\mathrm{a}, \mathrm{b}) \\
\left(\mu \mathrm{L} \mathrm{L}^{-1} \text { air }\right)\end{array}$ & $\chi^{2}$ & Slope \pm S.E. & Sig & $\mathrm{df}$ \\
\hline M. rotundifolia & $\begin{array}{l}32.71 \\
(-83.11-75.58)\end{array}$ & $\begin{array}{l}218.14 \\
(176.40-329.33)\end{array}$ & 2.97 & $0.009 \pm 0.002$ & 0.226 & 2 \\
\hline M. communis & $\begin{array}{l}357.67 \\
(291.15-789.02)\end{array}$ & $\begin{array}{l}530.69 \\
(394-1495.89)\end{array}$ & 1.18 & $0.010 \pm 0.004$ & 0.552 & 2 \\
\hline
\end{tabular}

a: Units $\mathrm{LC}_{50}$ and $\mathrm{LC}_{95}=\mu \mathrm{L} \cdot \mathrm{L}^{-1}$ air, applied for $18 \mathrm{~h}$ at $25^{\circ} \mathrm{C}$

b: $95 \%$ lower and upper confidence limits are shown in parenthesis

Table 3: $\mathrm{LT}_{50}$ values of Mentha rotundifolia and Myrtus communis essential oils applied by fumigation against Tribolium castaneum

\begin{tabular}{|c|c|c|c|c|c|c|c|}
\hline Essential oils & Concentrations ( $\mu \mathrm{L} \cdot \mathrm{L}^{-1}$ air $)$ & $\mathrm{LT}_{50}(\mathrm{a}, \mathrm{b})$ & $\mathrm{LT}_{95}(\mathrm{a}, \mathrm{b})$ & $x^{2}$ & Slope \pm S.E. & Sig & $\mathrm{df}$ \\
\hline \multirow[t]{4}{*}{ M. rotundifolia } & 65.8 & $\begin{array}{l}17.98 \\
(5.43-25.81)\end{array}$ & $\begin{array}{l}23.78 \\
(22.13-26.77)\end{array}$ & 10.94 & $0.306 \pm 0.029$ & 0.004 & 2 \\
\hline & 131.6 & $\begin{array}{l}15.21 \\
(14.63-15.78)\end{array}$ & $\begin{array}{l}19.32 \\
(18.49-20.45)\end{array}$ & 0.023 & $0.4 \pm 0.038$ & 0.989 & 2 \\
\hline & 197.36 & $\begin{array}{l}15.21 \\
(14.63-15.78)\end{array}$ & $\begin{array}{l}19.32 \\
(18.49-20.45)\end{array}$ & 0.023 & $0.4 \pm 0.038$ & 0.989 & 2 \\
\hline & 263.15 & $\begin{array}{l}13.2 \\
(12.65-15.19)\end{array}$ & $\begin{array}{l}15.6 \\
(14.2-21.53)\end{array}$ & 0.068 & $0.685 \pm 0.219$ & 0.967 & 2 \\
\hline \multirow[t]{4}{*}{ M. communis } & 65.8 & - & - & - & - & - & - \\
\hline & 131.6 & $\begin{array}{l}97.94 \\
(74.16-186.77)\end{array}$ & $\begin{array}{l}161.6 \\
(141.7-340.12)\end{array}$ & 2.53 & $0.026 \pm 0.008$ & 0.469 & 3 \\
\hline & 197.36 & $\begin{array}{l}49.36 \\
(37.06-278.77)\end{array}$ & $\begin{array}{l}84.22 \\
(58.73-849,07)\end{array}$ & 20.26 & $0.047 \pm 0.005$ & 0.00 & 3 \\
\hline & 263.15 & $\begin{array}{l}37.82 \\
(30.06-52.81)\end{array}$ & $\begin{array}{l}84.17 \\
(63.68-155.37)\end{array}$ & 6,342 & $0,035 \pm 0,004$ & 0.096 & 3 \\
\hline
\end{tabular}

a: Units $\mathrm{LT}_{50}=\mathrm{h}$, applied at $25^{\circ} \mathrm{C}$

b: $95 \%$ lower and upper confidence limits are shown in parenthesis

Table 4: Mortality (\%) of Tribolium castaneum adults exposed to various concentrations for different periods of time to Mentha rotundifolia and Myrtus communis essential oils applied by direct contact

\begin{tabular}{llllll}
\hline Concentration $\left(\mu \mathrm{L} \mathrm{cm}^{-2}\right)$ & $24 \mathrm{~h}$ & $48 \mathrm{~h}$ & $72 \mathrm{~h}$ & $96 \mathrm{~h}$ & $120 \mathrm{~h}$ \\
\hline 0.07 & $36.66 \pm 0.33 \mathrm{a}$ & $70 \pm 1 \mathrm{a}$ & $80 \pm 0.57 \mathrm{a}$ & $80 \pm 0.57 \mathrm{a}$ & $83.33 \pm 0.33 \mathrm{a}$ \\
0.11 & $50 \pm 0.57 \mathrm{a}$ & $90 \pm 0.57 \mathrm{~b}$ & $100 \pm 0 \mathrm{~b}$ & $100 \pm 0 \mathrm{~b}$ & $100 \pm 0 \mathrm{~b}$ \\
0.15 & $93.33 \pm 0.66 \mathrm{~b}$ & $100 \pm 0 \mathrm{~b}$ & $100 \pm 0 \mathrm{~b}$ & $100 \pm 0 \mathrm{~b}$ & $100 \pm 0 \mathrm{~b}$ \\
F- value & $\mathrm{F}=29.62$ & $\mathrm{~F}=5.25$ & $\mathrm{~F}=12$ & $\mathrm{~F}=12$ & $100 \pm 0$ \\
$P$ & $P \leq 0.01$ & $P \leq 0.05$ & $P \leq 0.001$ & $P \leq 0.001$ & $100 \pm 0$ \\
$P=25$ & $P \leq 0.001$ & \\
\hline For each column, values followed by different letters are significantly different according to Duncan test at $P \leq 0.05)$ &
\end{tabular}

Table 5: $\mathrm{LC}_{50}$ and $\mathrm{LC}_{95}$ of Mentha rotundifolia essential oil applied by contact test against Tribolium castaneum

\begin{tabular}{llllll}
\hline Essential oils & $\begin{array}{l}\mathrm{LC}_{50}(\mathrm{a}, \mathrm{b}) \\
\left(\mu \mathrm{L} \mathrm{cm}^{-2}\right)\end{array}$ & $\begin{array}{l}\mathrm{LC}_{95}(\mathrm{a}, \mathrm{b}) \\
\left(\mu \mathrm{L} \mathrm{cm}^{-2}\right)\end{array}$ & $\chi^{2}$ & Slope \pm S.E. & Sig \\
\hline M. rotundifolia & 0.113 & 0.164 & 1,223 & $32.26 \pm 3.04$ & 0,269 \\
& $(0.108-0.118)$ & $(0.155-0.177)$ & & & 1
\end{tabular}

a: Units $\mathrm{LC}_{50}$ and $\mathrm{LC}_{95}=\mu \mathrm{L} \mathrm{cm}^{-2}$, applied for $18 \mathrm{~h}$ at $25^{\circ} \mathrm{C}$

b: $95 \%$ lower and upper confidence limits are shown in parenthesis

results, the vapors of $M$. rotundifolia oil exhibited the highest fumigant toxicity against the tested fungi.

The study of different doses of $M$. rotundifolia essential oil effect on fungal growth showed that applied doses $\left(\mathrm{F}_{2,18}=5.06, P \leq 0.05\right)$ and the fungal strain are significant $\left(\mathrm{F}_{2,18}=12.55, P \leq 0.001\right)$. Indeed, $F$. solani was $100 \%$ inhibited with $8 \mu \mathrm{L}$ of oil vapor whereas; $B$. cinerea and $C$. acutatum were inhibited by 98.6 and $92.38 \%$ respectively (Fig. 6 and 7). At $10 \mu \mathrm{L}$ of $M$. rotundifolia oil, $B$. cinerea growth was $100 \%$ stopped while $C$. acutatum growth was inhibited by $97.25 \%$ (Fig. 6 and 7). These results suggest that 8,10 and $12 \mu \mathrm{L}$ are the corresponding MIC of $F$. solani, B. cinerea and $C$. acutatum respectively
(Table 7).

\section{Minimal fungicidal concentration}

The values of the minimal fungicidal concentrations of essential oils have been reported in Table 8. After ten days of incubation of the transferred mycelial discs, it has been noted that essential oil vapors presented fungistatic effects contrary to the direct contact application which possessed fungicidal activity. It was also observed that the minimal fungicidal concentrations values were higher than the minimal inhibitory concentrations. Minimal fungicidal concentration of $M$. rotundifolia for B. cinerea, C. acutatum 
Table 6: $\mathrm{LT}_{50}$ values of Mentha rotundifolia essential oil applied by direct contact against Tribolium castaneum

\begin{tabular}{|c|c|c|c|c|c|c|c|}
\hline Essential oils & Concentrations $\left(\mu \mathrm{L} \mathrm{cm}^{-2}\right)$ & $\mathrm{LT}_{50}(\mathrm{a}, \mathrm{b})$ & $\mathrm{LT}_{95}(\mathrm{a}, \mathrm{b})$ & $x^{2}$ & Slope \pm S.E. & Sig & df \\
\hline \multirow[t]{3}{*}{ M. rotundifolia } & 0.07 & $\begin{array}{l}37.14 . \\
(26.61-68.80)\end{array}$ & $\begin{array}{l}63.29 \\
(46.17-158.61)\end{array}$ & 23.30 & $0.063 \pm 0.005$ & 0.000 & 3 \\
\hline & 0.11 & $\begin{array}{l}20.38 \\
(17.06-23.35)\end{array}$ & $\begin{array}{l}57.71 \\
(50.23-69.88)\end{array}$ & 2.49 & $0.044 \pm 0.006$ & 0.287 & 2 \\
\hline & 0.15 & $\begin{array}{l}12.93 \\
(-50.18-17.25)\end{array}$ & $\begin{array}{l}23.18 \\
(18.44-161.50)\end{array}$ & 6.32 & $0.16 \pm 0.02$ & 0.042 & 2 \\
\hline
\end{tabular}

a: Units $\mathrm{LT}_{50}=\mathrm{h}$, applied at $25^{\circ} \mathrm{C}$

b: $95 \%$ lower and upper confidence limits are shown in parenthesis

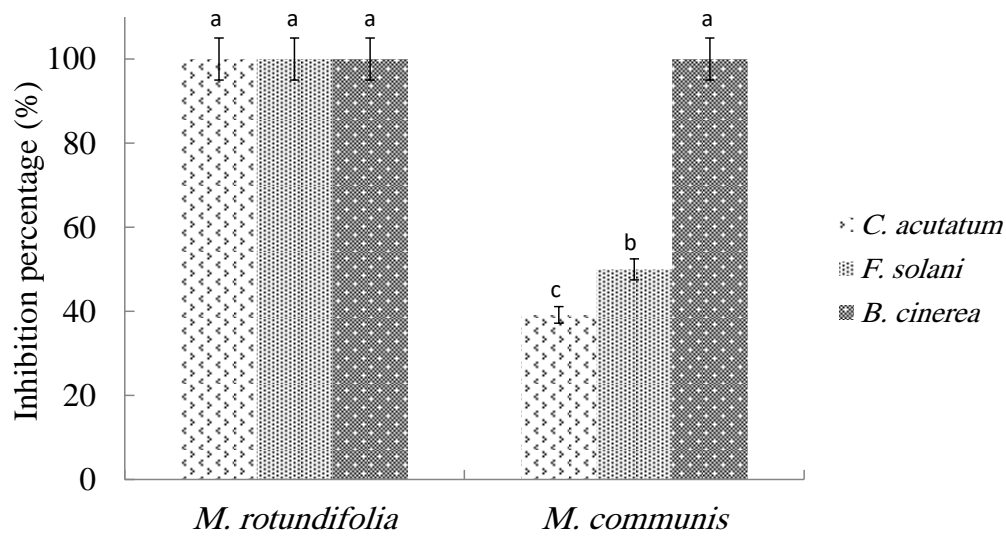

Fig. 2: Screening of contact antifungal activity of Mentha rotundifolia and Myrtus communis essential oils against Fusarium solani, Colletotrichum acutatum and Botrytis cinerea at $21.33 \mu \mathrm{L} \mathrm{mL}^{-1}$ concentration (Different letters are significantly different according to Duncan test at $P \leq 0.01$ )

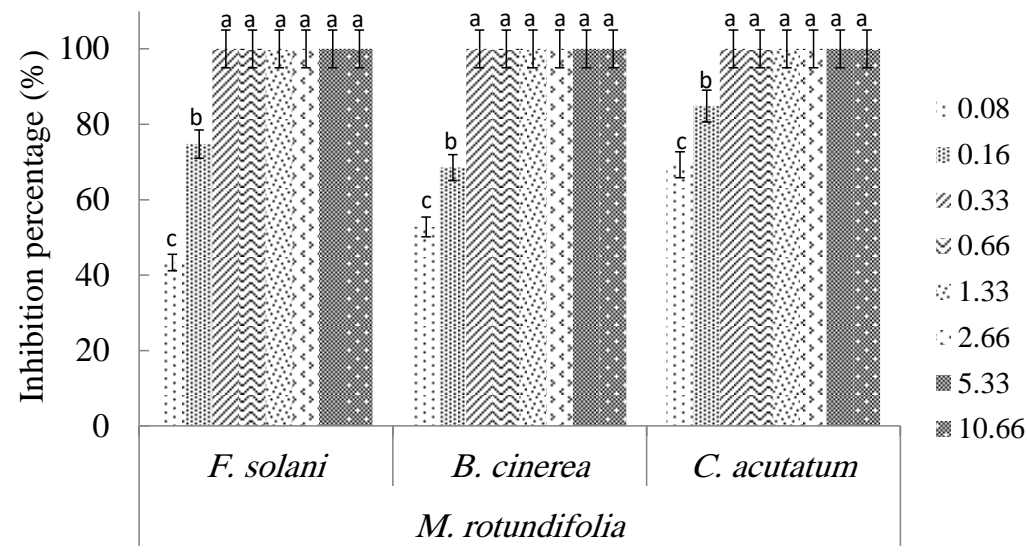

Fig. 3: Inhibition percentage induced by various concentrations of Mentha rotundifolia essential oil ( $\left.\mu \mathrm{L} \mathrm{mL}^{-1}\right)$ on the growth of Fusarium solani, Colletotrichum acutatum and Botrytis cinerea. Poisonous medium method (Different letters are significantly different according to Duncan test at $P \leq 0.01$ )

and $F$. solani were $0.66,1.33$ and $2.66 \mu \mathrm{L} \mathrm{mL}^{-1}$, respectively.

\section{Spore germination}

According to statistical analyses, $M$. rotundifolia crude essential oil inhibited $100 \%$ the germination of $B$. cinerea $\left(\mathrm{F}_{1,6}=19.57, P \leq 0.01\right)$ and $F$. solani spores $\left(\mathrm{F}_{1,6}=19422, P\right.$ $\leq 0.001$ ) comparing to controls and induced $51.11 \%$ of morphological modifications for B. cinerea and $99.94 \%$ for
F. solani conidia (Table 9 and Fig. 8).

\section{Discussion}

Biological potential of $M$. communis and $M$. rotundifolia essential oils have been little reported worldwide and especially in Algeria. However, these two aromatic plants widely distributed in the north of Africa, used to be largely recommended in traditional medicine to treat different health disorders. Based on these assumptions, Algerian 
Table 7: Minimum inhibitory concentrations (MIC) of Mentha rotundifolia essential

\begin{tabular}{lll}
\hline & Poisonous medium method $\left(\mu \mathrm{L} \mathrm{mL}^{-1}\right)$ & Volatile activity method $(\mu \mathrm{L})$ \\
\hline F. solani & 0.33 & 8 \\
B. cinerea & 0.33 & 10 \\
C. acutatum & 0.33 & 12
\end{tabular}

Oil against Fusarium solani, Botrytis cinerea and Colletotrichum acutatum

Table 8: Minimum fungicidal concentration (MFC) $\left(\mu \mathrm{L} \mathrm{mL}^{-1}\right)$ of Mentha rotundifolia essential oil against Fusarium solani, Botrytis cinerea and Colletotrichum acutatum with poisonous medium method

\begin{tabular}{ll}
\hline & Minimum fungicidal concentration $\left(\mu \mathrm{L} \mathrm{mL}^{-1}\right)$ \\
\hline F. solani & 2.66 \\
B. cinerea & 0.66 \\
C. acutatum & 1.33 \\
\hline
\end{tabular}

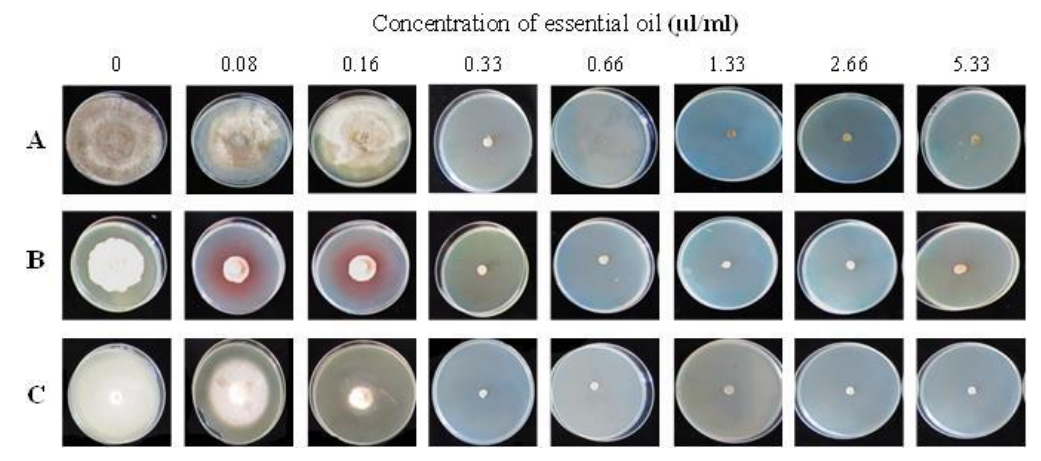

Fig. 4: Effect of various concentrations of Mentha rotundifolia essential oil on mycelial growth of (A) Botrytis cinerea; (B) Fusarium solani and (C) Colletotrichum acutatum on PDA

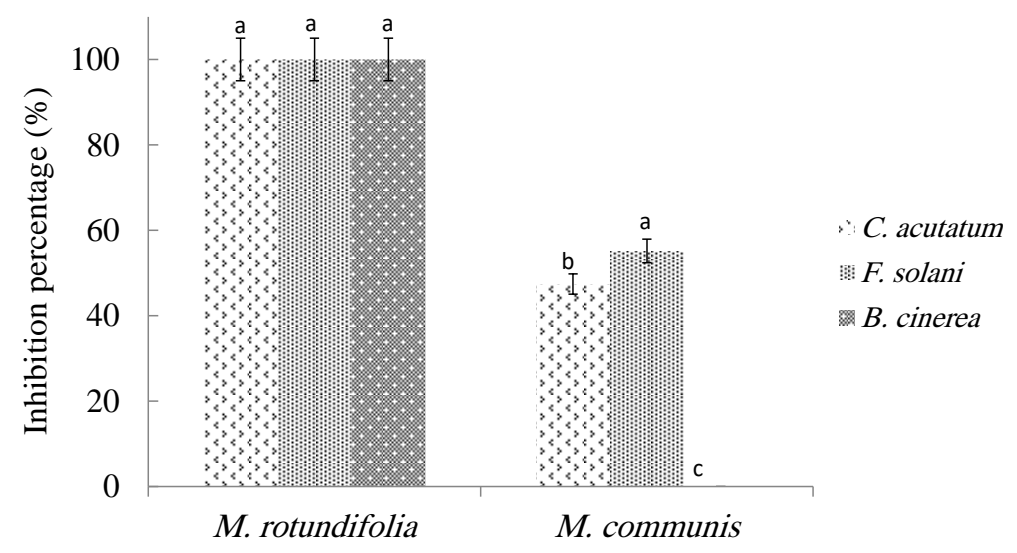

Fig. 5: Screening of volatile activity of Mentha rotundifolia and Myrtus communis essential oils vapor against Fusarium solani, Colletotrichum acutatum and Botrytis cinerea at $12 \mu \mathrm{L}$ dose. Different letters are significantly different according to Duncan test at $P \leq$ 0.01 )

M. communis and $M$. rotundifolia essential oils were screened for their chemical, insecticidal and antifungal properties in this study.

reported in some areas of Algeria and Tunisia (Bouzabata et al. 2010; Aidi-Wannes et al. 2010; Barhouchi et al. 2016) but greater to those stated by Jamoussi et al. (2005) in Tunisia, Farah et al. (2006) and Satrani et al. (2006) in Morocco, and Gardeli et al. (2008) in Greece. On the other hand, M. rotundifolia essential oil yielded $1.29 \%$ which is in agreement with the findings of Riahi et al. (2013) in Tunisia.

The extraction of essential oil from $M$. communis dry leaves allowed to obtain a yield $0.64 \%$ which is in accordance with the results reported in some areas of Algeria (Barhouchi et al. 2016) but greater than those observed in Tunisia (Jamoussi et al. 2005), in Morocco (Farah et al. 2006; Satrani et al. 2006), and in Greece (Gardeli et al. 2008). On the other hand, M. rotundifolia essential oil yielded $1.29 \%$ which is in agreement with the findings of Riahi et al. (2013) and different to those 
Table 9: Germination and morphological modifications (\%) of Fusarium solani and Botrytis cinerea spores treated by Mentha rotundifolia essential oil

\begin{tabular}{llll}
\hline & Fungi & M. rotundifolia & Control \\
\hline Germination (\%) & F. solani & $0^{\mathrm{a}}$ & $81.32^{\mathrm{b}}$ \\
& B. cinerea & $0^{\mathrm{a}}$ & $66.91^{\mathrm{b}}$ \\
Spores modification (\%) & F. solani & $99.94^{\mathrm{b}}$ & $0^{\mathrm{a}}$ \\
& B. cinerea & $51.11^{\mathrm{b}}$ & $0^{\mathrm{a}}$ \\
\hline
\end{tabular}

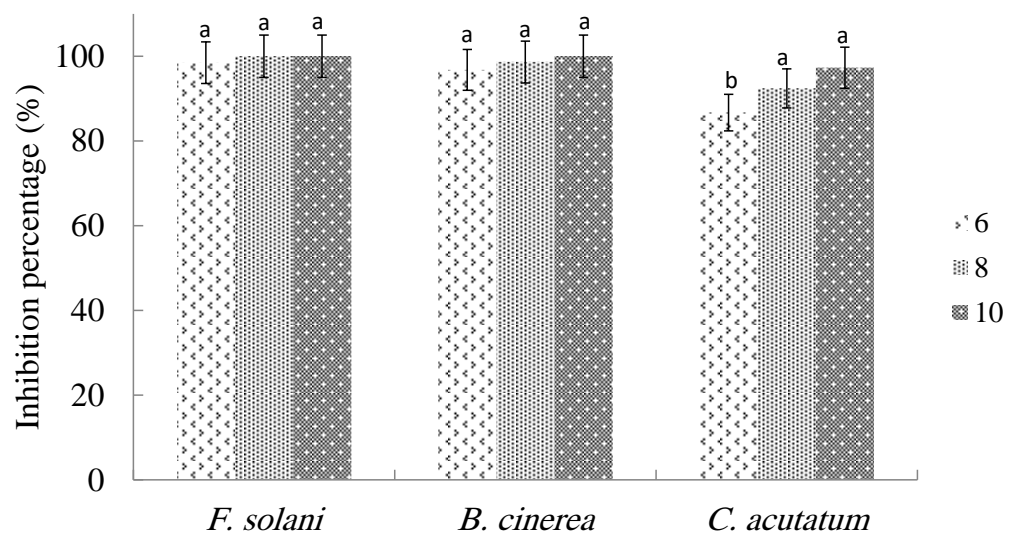

Fig. 6: Inhibition percentage induced by various concentrations of Mentha rotundifolia essential oil ( $\mu \mathrm{L})$ on the growth of Fusarium solani, Colletotrichum acutatum and Botrytiscinerea. Volatile activity method. Different letters are significantly different according to Duncan test at $P \leq 0.01$

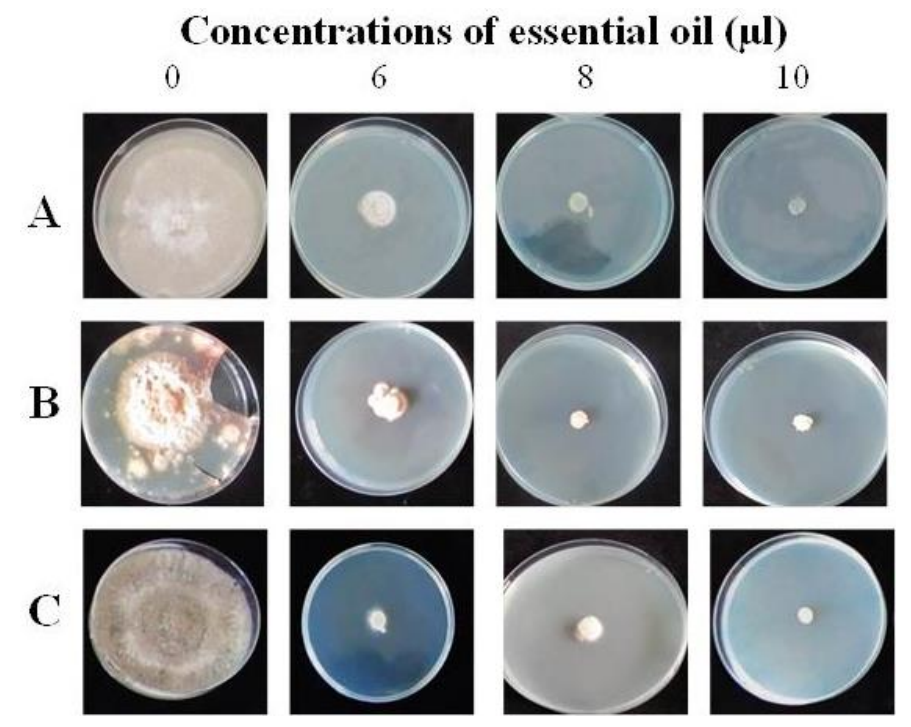

Fig. 7: Effect of various concentrations of Mentha rotundifolia essential oil on mycelial growth of (A) Colletotrichum acutatum; (B) Fusarium solani and (C) Botrytis cinerea on PDA

reported by other authors (Brahmi et al. 2016; Benabdallah et al. 2018).

Chemical analysis of the two essential oils showed that oxygenated monoterpenes class represented the major fraction of both essential oils with $72.94 \%$ in $M$. rotundifolia and $58.92 \%$ in $M$. communis followed by monoterpene hydrocarbons class which represents $35.25 \%$ for $M$. communis and $17.74 \%$ for $M$. rotundifolia. $M$. communis was dominated by 1,8 cineole $(36.82 \%)$ and $\alpha$ - pinene $(29.08 \%)$ while $M$. rotundifolia major compounds were rotundifolone $(46.06 \%)$ and D-limonene $(9.10 \%)$.

These findings are in accordance with those of Bouzouita et al. (2003) and Viuda-Martos et al. (2011). On the contrary, in precedent studies carried out by Bouzabata et al. (2010) and Barhouchi et al. (2016), the common myrtle of the same region was characterized by an $\alpha$-pinene essential oil chemotype. According to literature, the $\alpha$ pinene chemotype of the common myrtle essential oil is the 


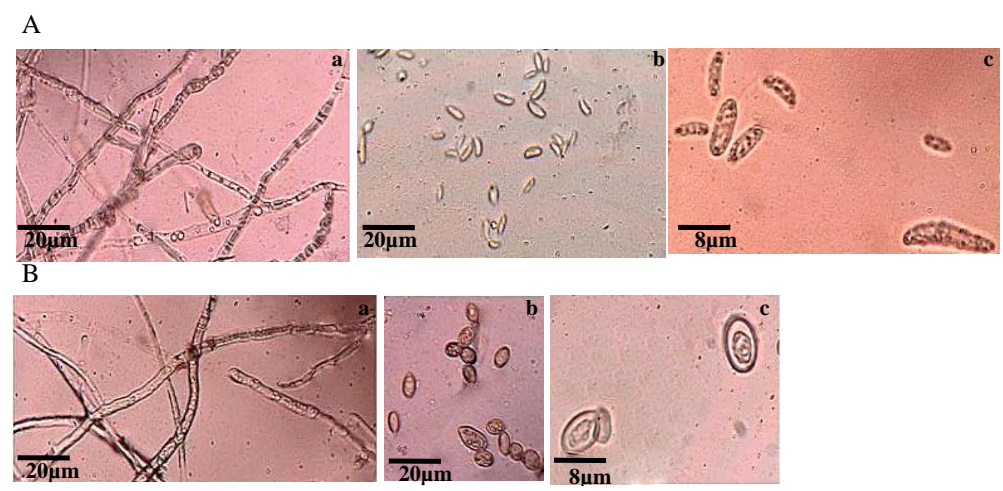

Fig. 8: Micrography displaying the effect of Mentha rotundifolia essential oil treatment on (A) Fusarium solani and (B) Botrytis cinerea conidia

a: untreated germinated conidia (positive control); b: Absence of germination of treated conidia; $\mathbf{c}$ : Treated conidia showing structure modifications

most widespread around the world; it is the typical chemotype of Tunisian M. communis wild populations (Ghnaya et al. 2013), Albanian ones (Asllani 2000), Iranian (Bajalan and Pirbalouti 2014) French (Curini et al. 2003), Iraqi (Kiralan et al. 2012) and Italian (Mulas and Melis 2011). However, other chemotypes of $M$. communis essential oil have been identified in other regions of Algeria such as 1,8-cineole/cis-geraniol in TiziOuzou and myrtenyl acetate/1,8-Cineole in Algiers (Djenane et al. 2011). On another side, Myrtenyl acetate chemotype characterized Grecian Spanish and Croatian myrtle essential oil (Jerkovic et al. 2002; Gardeli et al. 2008). Otherwise, a 1,8cineole/linalool chemotype has been reported in Turkish myrtle essential oil (Özek et al. 2000) while the Moroccan M. communis essential oil was dominated by the pair 1,8 cineole/myrtenyle acetate (Farah et al. 2006).

In our study, oxygenated monoterpenes chemical class exceeded the level of $50 \%$ of the chemical composition of M. rotundifolia essential oil (72.94\%). M. rotundifolia essential oil belonged to piperitenone oxide chemotype. In accordance with our results, piperitenone oxide chemotype was recorded to be the main constituent of $M$. rotundifolia species in different geographic regions around the world (Bounihi 2016; Benabdallah et al. 2018). Nevertheless, Brahmi et al. (2016) stated trans-piperitone epooxide as main constituent of $M$. rotundifolia growing in BejaiaAlgeria. Moreover, M. rotundifolia essential oil with the germacrene chemotype was identified in ConstantineAlgeria (Bouhabila et al. 2018). Pulegone was identified as the main chemical component of Tunisian and Moroccan species (Riahi et al. 2013. Menthol chemotype was also reported in Morocco (Derwich et al. 2009). Furthermore, Lawrence (2007) reported a carvone chemotype of $M$. rotundifolia oil. Additionally, Piperitone oxide and menthyl acetate were also found to be two chemotypes of the Grecian specie (Kokkini and Papageorgiou 1988). Whereas, 2, 4 (8), 6-p-menthatrien-2, 3-diol and germacrene D chemotypes characterized Cuban $M$. rotundifolia populations (Pino et al. 1999).

Subsequently to chemical composition determination, data of the current study indicated that $M$. rotundifolia and $M$. communis essential oils expressed fumigant activity against $T$. castaneum, with a better activity of $M$. rotundifolia. Indeed, $T$. castaneum adults were about six times more susceptible to the fumigant toxicity of $M$. rotundifolia than $M$. communis essential oils.

In contrast with our finding, Karabörklü et al. (2010) reported that Turkish $M$. communis essential oil possessed a strong fumigant activity against $T$. castaneum with a low $\mathrm{LC}_{50}$ value $\left(56.98 \mu \mathrm{L} \mathrm{L}^{-1}\right.$ air). Opposing to $M$. rotundifolia which exhibited an interesting contact activity, $M$. communis essential oil was completely ineffective against $T$. castaneum adults. To the best of our knowledge, no published data has previously been reported on the insecticidal activity of Algerian $M$. rotundifolia essential oil on $T$. castaneum. However, $M$. rotundifolia essential oil was assessed for its insecticidal effect on other insects. Thus, Brahmi et al. (2016) investigated the insecticidal potential of piperitone epoxide chemotype of Algerian $M$. rotundifolia (Bejaia, Algeria) against Rhyzopertha dominica and reported the moderate contact and fumigant toxicity of the essential oil. Arch et al. (2003) stated that Moroccan pulegone chemotype of $M$. rotundifolia essential oil presented an interesting fumigant activity. $100 \%$ mortality was reached after $24 \mathrm{~h}$ of exposure to $35 \mu \mathrm{L} \mathrm{L}^{-1}$ air and 65 $\mu \mathrm{L} \mathrm{L}^{-1}$ air for Sitophilus oryzae and $R$. dominica, respectively.

According to our results, insecticidal activity of the tested oils varied conferring to the mode of application. $M$. rotundifolia oil displayed more strength in contact toxicity than fumigant activity. Contrary, essential oil of $M$. communis showed moderate fumigant toxicity while it has no toxic effect in contact assay. This is in agreement with the findings of Zapata and Smagghe (2010). The same conclusion was made by Mohamed and Abdelgaleil (2008) when they screened the fumigant and contact effect of essential oils extracted from eight Egyptian aromatic plants against $T$. castaneum adults. They found that all the tested essential oil possessed a better contact toxicity than fumigant toxicity apart Mentha microphylla which was the 
strongest one ever tested as well in fumigant test $\left(\mathrm{LC}_{50}=\right.$ $4.51 \mu \mathrm{L} \mathrm{L}^{-1}$ air $)$ as in contact test $\left(\mathrm{LC}_{50}=0.01 \mathrm{mgcm}^{-2}\right)$. Several investigations testified the interesting insecticidal potential of many species of the genus Mentha against $T$. castaneum (Eliopoulos et al. 2015; Kasrati et al. 2015). On the bases of the low $\mathrm{LC}_{50}$ values in contact $\left(0.11 \mu \mathrm{L} \mathrm{cm}^{-2}\right)$ and fumigant $\left(32.71 \mu \mathrm{L} \mathrm{L}^{-1}\right.$ air) activity of our study, $M$. rotundifolia oil revealed a strong insecticidal potential against stored product pests. This effective activity could be attributed to its major components: piperitenone oxide DLimonene and Cis piperitone oxide. Oumzil et al. (2002), reported an antibacterial activity of piperitenone oxide and piperitone oxide. Additionally, Tripathi et al. (2004) studied the insecticidal effect of piperitenone oxide against various stage of Anopheles stephensi and indicated a high level of toxicity, repellency and decreasing of reproduction parameters. Many reports related the fumigant, contact and antifeedant toxicity of 1,8 cineol, which is the major component of $M$. communis essential oil (Lee et al. 2004; Rozman et al. 2007; Palacios et al. 2009). Moreover, the insecticidal activity of several essential oils major components against $T$. castaneum has been reported in several researches (Mondal and Khalequzzaman 2010; Eljazi et al. 2018). Generally, essential oils and their main components act on the nervous system of the insect either by inhibiting the activity of the enzyme acetylcholinesterase or by increasing the concentrations of cAMP and $\mathrm{Ca}^{2+}$ in nervous cells or as an antagonist to octopamine receptors (exclusive to invertebrates including insects) (Jankowska et al. 2017). According to the same authors, the multitude potential target sites in the nervous system of insects make essential oils components interesting candidates for bio-insecticides. Numerous papers have reported the antifungal activity of $M$. communis and $M$. rotundifolia essential oil against human pathogenic fungi, but few studies have been carried out on phytopathogenic strains. To the best of our knowledge, no previous study has reported the antifungal toxicity of Algerian $M$. rotundifolia and $M$. communis essential oils.

Results obtained from our study revealed that essential oils extracted from $M$. rotundifolia exhibited a powerful antifungal activity. In vitro tests have shown that $M$. rotundifolia was very effective against all fungal strains in comparison with $M$. communis essential oil, which was effective only by contact application on $B$. cinerea. Our results corroborate those of Curini et al. (2003) showing that the essential oil of the Italian species of Myrtus communis had also exerted a weak inhibitory power on the mycelial growth of $F$. solani $(15,59 \%$ inhibition at $1600 \mathrm{ppm})$. The same observations were reported for the Tunisian species for which the essential oil with chemotype $\alpha$ pinene/Limonene had slightly reduced the mycelial growth of $F$. solani to $32 \%$ at the concentration of $10 \mu \mathrm{L} \mathrm{mL}^{-1}$ (Slim et al. 2017). Besides, according to Mirzabagheri et al. (2014), Iranian common myrtle essential oil has shown the weakest antifungal activity against Penicellium digitatum compared to other essential oils.

It should be noted that the sensitivity of microorganisms to the action of essential oils varied considerably depending on the method of application. Indeed, $M$. rotundifolia essential oil possessed a fungitoxic potential by contact unlike the vapors which exerted a fungistatic effect by fumigation. Likewise, the essential oil of $M$. communis was effective against $B$. cinerea by contact and completely ineffective by fumigation. Our findings corroborate the results of Regnier et al. (2014) which indicated the fungitoxic and the fungistatic effects of essential oils by contact and fumigation application respectively. According to Cox et al. (2001), the variability in essential oil efficacy related to the mode of application (contact or fumigation) can be explained by the differences in the polarities and volatilities of the individual essential oil components. Hydrophilic polar constituents mix and diffuse easily in aqueous media and consequently exhibit higher effects in direct contact method. Referring to the minimum inhibitory and fungicidal concentrations, $M$. rotundifolia expressed a strong antifungal toxicity; $C$. acutatum, $F$. solani and $B$. cinerea colonies were completely inhibited at the low concentration of $0.33 \mu \mathrm{L} \mathrm{mL} \mathrm{mL}^{-1}$. Moreover, $M$. rotundifolia essential oil vapors even entirely stopped the mycelial growth of $F$. solani, B. cinerea and $C$. acutatum at the low concentrations of 8,10 and $12 \mu \mathrm{L}$ respectively. Previous studies attested the toxicity of round leaf mint essential oil and its main components against several micro-organisms strains (Ladjel et al. 2011). This powerful antifungal ability of $M$. rotundifolia essential oil can be attributed to its main chemical components and their synergistic action with minor components (Mahboubi and Haghi 2008). Essential oils with a high level of oxygenated monoterpenes components are biologically more active compared to oils rich in hydrocarbon monoterpenes (Carson and Riley 1995), which is the case with our findings. Other species of Mentha genus had also displayed an effective antifungal activity such as M. spicata, M. pulegium (Yadav et al. 2006; Mohammadi et al. 2013), M. arvensis (Kumar et al. 2009) and M. piperita (Plavšić et al. 2017) against Alternaria alterna $(700 \mathrm{ppm})$, Pyricularia oryzae, Penicillium digitatum (1000 ppm), Aspergillus ochraceus (1100 ppm), F. oxysporum, f. spp. ciceris, Macrophominaphaseolina, Dreshlera spicifera and Eurotium herbariorum. These essential oils act on the fungus by altering the mycelium but also by inhibiting spores germination. $M$. rotundifolia inhibited completely the spore germination of $F$. solani and $B$. cinerea. The essential oil has also induced morphological changes in the spores causing up to the exuviation of cellular content. The inhibitory action of essential oils on the germination of fungal spores has been underlined in several works (Vitoratos et al. 2013; Farzaneh et al. 2015). The mechanism of antifungal action of essential oils remains ambiguous and misunderstood. Nevertheless, previous studies have shown that the antifungal activity of essential oils is due to their ability to disrupt the structure of cell 
membranes in fungi (Pei et al. 2020). According to Shao et al. (2013), tea tree essential oil altered mycelial morphology and ultrastructure. The low ratio of unsaturated/saturated fatty acids increases the permeability and electrical conductivity of the membrane and causes the exuviation of cytoplasm. Based on the results of our study, the strong insecticidal and antifungal potential expressed by the essential oil of round-leaved mint can be exploited in biological control as part of pest control strategies within the framework of sustainable development.

\section{Conclusion}

In conclusion, our research pointed out the potent antifungal and insecticidal activity of Mentha rotundifolia essential oil. Indeed, on the one hand, it acted effectively on the three tested fungal strains by inhibiting completely their mycelial growth at low concentrations and by stopping totally the spore's germination by inducing deep alterations in their morphologies leading even to their explosion. On the other hand, it caused the complete death of Ephestia kuehniella adults by contact and fumigation application. Therefore, our results support the use of $M$. rotundifolia oil in the biological control of stored foods pests and diseases. Nevertheless, additional tests on the impact of essential oil on food quality as well as in vivo tests on artificially inoculated fruits are needed.

\section{Author Contributions}

GA and LKG did data curation, formal analysis, writing original draft editing. AS, SH and MBA wrote methodology, and involved in writing-revision. TF was Project administration. SEK, EB and MC involved in resource management. MRH did supervision; validation. JMBJ was involved in conceptualization, supervision and validation.

\section{Conflicts of Interest}

All authors declare no conflicts of interest.

\section{Data Availability}

Data presented in this study will be available on a fair request to the corresponding author.

\section{Ethics Approval}

Not applicable in this paper

\section{References}

Abott W (1925). A method of computing the effectiveness of an insecticide. J Econ Entomol 18:265-267

Afnor (1986). Recueil des normes Françaises huiles essentielles, p:57. AFNOR, Paris, France
Aidi-Wannes W, B Mhamdi B Marzouk (2007). Essential oil composition of two Myrtus communis $\mathrm{L}$. varieties grown in North Tunisia. Ital J Biochem 56:180-186

Ali A, A Javaid, A Shoaib, IH Khan (2020). Effect of soil amendment with Chenopodium album dry biomass and two Trichoderma species on growth of chickpea var. Noor 2009 in Sclerotium rolfsii contaminated soil. Egypt J Biol Pest Cont 30:1-9

Aouadi G, S Haouel, A Soltani, MB Abada, E Boushih, S Elkahoui, F Taibi, JMB Jemâa, S Bennadja (2020). Screening for insecticidal efficacy of two Algerian essential oils with special concern to their impact on biological parameters of Ephestia kuehniella (Lepidoptera: Pyralidae). J Plant Dis Prot 127:471-482

Arch ME, B Satrani, A Farah, L Bennani, D Boriky, M Fechtal, M Blaghen, M Talbi (2003) Composition chimique et activité antimicrobienne et insecticide de l'huile essentielle de Mentha rotundifolia du Maroc. Acta Bot Gall 150:267-274

Asllani U (2000). Chemical composition of Albanian myrtle oil (Myrtus communis L.). J Essent Oil Res 12:140-142

Bajalan I, AG Pirbalouti (2014). Variation in antibacterial activity and chemical compositions of essential oil from different populations of myrtle. Ind Crop Prod 61:303-307

Bakkali F, S Averbeck, D Averbeck, M Idaomar (2008). Biological effects of essential oils- A review. Food Chem Toxicol 46:446-475

Banaras S, A Javaid, IH Khan (2021). Bioassays guided fractionation of Ageratum conyzoides extract for the identification of natural antifungal compounds against Macrophomina phaseolina. Intl $J$ Agric Biol 25:761-767

Banaras S, A Javaid, IH Khan (2020). Potential antifungal constituents of Sonchus oleraceous against Macrophomina phaseolina. Intl J Agric Biol 24:1376-1382

Bande-Borujeni S， N Zandi-Sohani, L Ramezani (2018). Chemical composition and bioactivity of essential oil from Eucalyptus occidentalis leaves against two stored product pests. Intl J Trop Ins Sci 38:216-223

Barhouchi B, S Aouadi, A Abdi (2016). Essential oil chemical composition of myrtle growing in Northeastern Algeria and estimation of its antibacterial effectiveness. Amer J Biochem Biotechnol 12:110-121

Benabdallah A, M Boumendjel, O Aissi, C Rahmoune, M Boussaid, C Messaoud (2018). Chemical composition, antioxidant activity and acetylcholinesterase inhibitory of wild Mentha species from northeast Algeria. S Afr J Bot 116:131-139

Boudjelal A, C Henchiri, M Sari, D Sarri, N Hendel, A Benkhaled, G Ruberto (2013). Herbalists and wild medicinal plants in M'sila (North Algeria). An ethnopharmacology survey. J Ethnopharmacol 148:395-402

Bouhabila A, I Telsi, S Maarfia, N Gherraf (2018). Changeability of essential oils in Algerian Mentha rotundifolia L. (Lamiaceae) growing in sub humid area. World J Environ Biosci 7:45-47

Bounihi A (2016). Criblage phytochimique, Étude toxicologique et valorisation pharmacologique de Melissa officinalis et de Mentha rotundifolia (Lamiacées). Thèse de doctorat. Faculté de médecine et de pharmacie. Université Mohammed V, Rabat. Morocco

Bouzabata A, F Boussaha, J Casanova, F Tomi (2010). Composition and chemical variability of leaf oil of Myrtus communis from NorthEastern Algeria. Nat Prod Commun 5:1659-1662

Bouzouita N, F Kachouri, M Hamdi, M Chaabouni (2003). Antimicrobial activity of essential oils from Tunisian aromatic plants. Flav Fragr J 18:380-383

Brahmi F, A Abdenour, M Bruno, P Silvia, P Alessandra, F Danilo, D Yalaoui-Guellal, MF Elsebai, K Madani, M Chibane (2016). Chemical composition and in vitro antimicrobial, insecticidal and antioxidant activities of the essential oils of Mentha pulegium L. and Mentha rotundifolia growing in Algeria. Industr Crop Prod 88:96105

Cakir A, S Kordali, H Kilic, E Kaya (2005). Antifungal properties of essential oil and crude extracts of Hypericum Linarioides Bosse. Biochem Syst Ecol 33:245-256

Carson CF, TV Riley (1995). Antimicrobial activity of the major components of the essential oil of Melaleuca alternifolia. J Appl Bacteriol 78:264-269 


\section{Plant Extracts for the Pest Management of Stored Products / Intl J Agric Biol, Vol 26, No 6, 2021}

Chandrasekaran M, B Thangavelu, SC Chun, M Sathiyabama (2016). Proteases from phytopathogenic fungi and their importance in phyto pathogenicity. J Gen Plant Pathol 82:233-239

Cheraif K, B Bakchiche, A Gherib, SK Bardaweel, MC Ayvaz, G Flamini, R Ascrizzi, MA Ghareeb (2020). Chemical composition, antioxydant, anti-tyrosinase, anti-Cholinesterase and cytotoxic activities of essential oils of six Algerian plants. Molesules 25; Article 1710

Cox SD, CN Mann, JL Markham (2001). Interactions between components of the essential oil of Malaleuca alternifolia. Soc Appl Microbiol 91:492-497

Curini M, A Bianchi, F Epifano, R Bruni, L Torta, A Zambonelli (2003). Composition and in vitro antifungal activity of essential oils of Erigeron canadensis. Chem Nat Comp 39:191-194

Dean R, JALV Kan, ZA Pretorius, KE Hammond-Kosack, AD Pietro, PD Spanu, JJ Rudd, M Dickman, R Kahmann, J Ellis, GD Foster (2012). The top 10 fungal pathogens in molecular plant pathology. Mol Plant Pathol 13:414-430

Derwich E, Z Benziane, A Boukir, L Benaabidate (2009). GC-MS analysis of the leaf essential oil of Mentha rotundifolia, a traditional herbal medicine in Morocco. Chem Bull Politech Univ Timis 54:85-88

Djenane D, J Yangüela, T Amrouche, S Boubrit, N Boussad, P Roncalés (2011). Chemical composition and antimicrobial effects of essential oils of Eucalyptus globulus, Myrtus communis and Saturejahortensis against Escherichia coli O157:H7 and Stapphylococcus aureus in minced beef. Food Sci Technol Intl 17:505-515

Elad Y, M Vivier, S Fillinger (2016). Botrytis, the good, the bad and the ugly. In: Botrytis - the Fungus, the Pathogen and its Management in Agrucultar Systems. Fillinger S, Y Elad (Eds). Springer, Cham, Switzerland

Eliopoulos P, C Hassiotis, S Andreadis, A Porichi (2015). Fumigant toxicity of essential oils from basil and spearmint against two major pyralid pests of stored products. $J$ Econ Entomol 108:805-810

Eljazi J, O Bachrouch, N Salem, K Mssada, J Aouini, M Hammami, E Boushih, M Abderraba, F Limam, JMB Jemâa (2018). Chemical composition and insecticidal activity of essential oil from coriander fruit against Tribulium castaneum, Sitophilus oryzae and Lasioderm aserricorne. Intl J Food Prop 20:2833-2845

Farah A, A Afifi, M Fechtal, A Chhen, B Satrani, M Talbi, A Chaouch (2006). Fractional distillation effect on the chemical composition of Moroccan Myrtle (Myrtus communis L.) essential oils. Flav Fragr J 21:274-277

Farzaneh M, H Kiani, R Sharifi, M Reisi, J Hadian (2015). Chemical composition and antifungal effects of three species of Satureja ( $S$. hortensis, $S$. spicigera and $S$. khuzistanica) essential oils on the main pathogens of strawberry fruit. Postharv Biol Technol 109:145-151

Fujita KI, I Kubo (2004). Potentiation of fungicidal activities of transanethole against Saccharomyces cerevisiae under hypoxic conditions. J Biosci Bioeng 98:490-492

Gardeli C, P Vassiliki, M Athanasios, T Kibouris, M Komaitis (2008). Essential oil composition of Pistacia lentiscus L. and Myrtus communis L: Evaluation of antioxidant capacity of methanolic extracts. Food Chem 107:1120-1130

Ghnaya AB, H Chograni, C Messoud, M Boussaid (2013). Comparative chemical composition and antibacterial activities of Myrtus communis L. essential oils isolated from Tunisian and Algerian population. J Plant Pathol Microbiol 4:7

Haouel S, JMB Jemâa, ML Khouja (2010). Postharvest control of the date moth Ectomyeloisceretoniae using Eucalyptus essential oil fumigation. Tunis J Plant Prot 5:201-212

Jamoussi B, M Romdhane, A Abderraba, BB Hassine, AE Gadri (2005). Effect of harvest time on the yield and composition of Tunisian Myrtle oils. Flav Fragr J 20:274-277

Jankowska M, J Rogalska, J Wyszkowska, M Stankiewicz (2017). Molecular targets for components of essential oils in the insect nervous system-A review. Molecules 23; Article 34

Javed S, Z Mahmood, KM Khan, SD Sarker, A Javaid, IH Khan, A Shoaib (2021). Lupeol acetate as a potent antifungal compound against opportunistic human and phytopathogenic mold Macrophomina phaseolina. Sci Rep 11; Article 8417
Jerkovic I, A Radonic, I Borcic (2002). Comparative study of leaf, fruit and flower essential oils of Croatian Myrtus communis (L.) during a oneyear vegetative cycle. J Essent Oil Res 14:266-270

Júnior S, NP Stamford, MAB Lima, TMS Arnaud, MM Pintado, BF Sarmento (2014). Characterization and inhibitory activity of chitosan on hyphae growth and morphology of Botrytis cinerea plant pathogen. Intl J Appl Res Nat Prod 7:31-38

Karabörklü S, A Ayvaz, S Yilmaz (2010). Bioactivities of different essential oils against the adults of two stored products insects. Pak J Zool 42:679-686

Kasrati A, CA Jamali, K Bekkouche, R Spooner-Hart, D Leach, A Abbad (2015). Chemical characterization and insecticidal properties of essential oils from different wild populations of Mentha suaveolens subspp. Timija (Briq) Harley from Morocco. Chem Biodivers 12:823-831

Khan IH, A Javaid, AH Al-Taie, D Ahmed (2020). Use of neem leaves as soil amendment for the control of collar rot disease of chickpea. Egypt J Biol Pest Cont 30:1-8

Kharoubi R, N Rehimi, N Soltani (2020). Essential oil from Mentha rotundifolia harvested in Northeast Algeria: chemical composition, larvicidal and enzymatic activities on Culex pipiens larvae. Transylv Rev 27:14724-14732

Kiralan M, A Bayrak, F Abdulaziz, T Zbucak (2012). Essential oil composition and antiradical activity of the oil of Iraq plants. Nat Prod Res 26:132-139

Kokkini S, V Papageorgiou (1988). Constituents of essential oils from Mentha X rotundifolia growing wild in Greece. Plant Med 54:166167

Kumar A, R Shukla, P Singh, AK Singh, NK Dubey (2009). Use of essential oil from Mentha arvensis L. to control storage moulds and insects in stored chickpea. J Sci Food Agric 89:2643-2649

Kumar P, S Mishra, A Malik, S Satya (2011). Insecticidal properties of Mentha species: A review. Ind Crops Prod 34:802-817

Ladjel S, N Gherraf, D Hamada (2011). Antimicrobial effect of essential oils from the Algerian medicinal plant Mentha rotundifolia L. J Appl Sci Res 7:1665-1667

Lawrence B (2007). Mint: the genus Mentha. Boca Raton, Medicinal and aromatic plants-industrial profiles, p:556. CRC Press, Boca Raton, Florida, USA

Leblalta A, D Harzallah, S Cherrad, D Ibrahim (2020). Antifungal activity of Mentha rotundifolia essential oil against Fusarium oxysporum. Intl J Innov Approach Agric Res 4:56-68

Lee BH, PC Annis, F Tumaalii, WS Choi (2004). Fumigant toxicity of essential oils from the Myrtaceae family and 1, 8-cineole against 3 major stored-grain insects. J Stored Prod Res 40:553-564

Mahboubi M, G Haghi (2008). Antimicrobial activity and chemical composition of Mentha pulegium L. essential oil. J Ethnopharmacol 119:325-327

Mirzabagheri D, M Abbaszadeh, MM Akbarian, S Derijani, S Sadradini (2014). Inhibition effects of Zataria multiflora, Eucalyptus camaldulensis and Myrtus communis essential oil on mycelial growth of green mold of orange. Intl J Adv Biol Biomed Res 2:8699

Mohamed MIE, SAM Abdelgaleil (2008). Chemical composition and insecticidal potential of essential oils from Egyptian plants against Sitophilus oryzae (L.) (Coleoptera: Curculionidae) and Tribulium castaneumHerbst (Coleoptera: Tenebrionidae). Appl Entomol Zool 43:599-607

Mohammadi P, N Lotfi, L Naseri, HR Etebarian (2013). Antifungal activities of essential oils from some Iranian medicinal plants against various post-harvest moulds. J Med Plant Res 7:1699-1708

Mondal M, M Khalequzzaman (2010). Toxicity of naturally occurring compounds of plant essential oil against Tribulium castaneum Herbst. J Biol Sci 10:10-17

Mulas M, RAM Milis (2011). Essential oil composition of Myrtle (Myrtus communis) leaves. J Herbs Spices Med Plants 17:21-34

Neri F, M Mari, S Brigati (2006). Control of Penicillium expansum by plant volatile compounds. Plant Pathol 55:100-105

Nunes CA (2012). Biological control of postharvest diseases of fruit. Eur J Plant Pathol 133:181-196 
Oumzil H, S Ghoulami, M Rhajaoui, Allidrissi, S FkihTetouani, M Faid, M Benjouad (2002). Antibacterial and antifungal activity of essential oils of Mentha suaveolens. Phytother Res Intl J Devot Pharm Toxicol Evaluat Nat Prod Derivat 16:727-731

Özek T, B Demirci, KHC Baser (2000). Chemical composition of Turkish Myrtle oil. J Essent Oil Res 12:541-544

Palacios SM, A Bertoni, Y Rossi, R Santander, A Urzúa (2009). Efficacy of essential oils from edible plants as insecticides against the house fly, Musca Domestica L. Molecules 14:1938-1947

Pei S, R Liu, H Gao, H Chen, W Wu, X Fang, Y Han (2020). Inhibitory effect and possible mechanism of carvacrol against Colletotrichum fruticola. Postharv Biol Technol 163:111-126

Pimentel MAG, LR Faroni, MR Totola, RN Guedes (2007). Phosphine resistance, respiration rate and fitness consequences in stored-product insects. Pest Manage Sci 63:876-881

Pino J, A Rosado, V Fuentes (1999). Chemical composition of the leaf oil of Mentha rotundifolia (L.) Hudson from Cuba. J Essent Oil Res 11:241-242

Plavšić D, GR Dimić, DB Psodorov, DD Psodorov, LĆ Šarić, IS Čabarkapa, MB Košutić (2017). Antifungal activity of Mentha piperita and Carumcarvi essential oils. Maticasrps J Nat Sci Novi Sad 133:201-207

Plaza P, R Torres, J Usall, N Lamarca, I Viňas (2004). Evaluation of potential of commercial post-harvest application of essential oils to control citrus decay. J Hortic Sci Biotechnol 79:935-940

Rahali N, S Mehdi, F Younsi, M Boussaid, C Messaoud (2017). Antioxidant, $\alpha$-amylase and acetycholinesterase inhibitory activities of Hertia cheirifolia essential oils: Influence of plant organs and seasonal variation. Intl J Food Prop 20:1637-1651

Regnier T, S Combrinck, W Veldman (2014). Application of essential oils as multi-target fungicides for the control of Geotrichumcitri-aurantii and other postharvest pathogens of citrus. Ind Crops Prod 61:151159

Regnier T, WD Plooy, S Combrinck, B Botha (2008). Fungitoxicity of Lippia scaberrima essential oil and selected terpenoid components on two mango postharvest spoilage pathogens. Posthav Biol Technol 48:254-258

Riahi L, M Elferchichi, H Ghazghazi, J Jebali, C Aouadhi, H Chogran, Y Zaouali, N Zoghlami, A MLiki (2013). Phytochemistry, antioxidant and antimicrobial activities of the essential oils of Mentha rotundifolia L. in Tunisia. Ind Crop Prod 49:883-889

Rozman V, I Kalinovic, Z Korunic (2007). Toxicity of naturally occurring compounds of Lamiaceae and Lauraceae of three stored-product insects. J Stor Prod Res 43:349-355

Salehi B, Z Stojanović-Radić, J Matejić, F Sharopov, H Antolak, D Kregiel, K Dorota, S Sen, MS Rad, K Acharya, RS Rad, M Martorell, A Sureda, N Martins, JS Rad (2018). Plants of genus Mentha: From farm to food factory. Plants 7:70
Salem N, O Bachrouch, J Sriti, K Msaada, S Khammassi, M Hammami, S Selmi,EBoushih, S Koorani, M Abderraba, B Marzouk, FLimam, JMB Jemâa (2018). Fumigant and repellent potentials of Ricinus communis and Mentha pulegium essential oils against Tribulium castaneum, and Lasioderma serricorne. Intl J Food Prop 20:2899-2913

Satrani B, A Farah, M Talbi (2006). Effet de la distillation fractionnée sur la composition chimique et l'activité antimicrobienne des huiles essentielles du Myrte (Myrtus communis L) du Maroc. Acta Bot Gall 153:235-242

Shao X, S Cheng, H Wang, D Yul, C Mungai (2013). The possible mechanism of antifungal action of tea tree oil on Botrytis cinerea. $J$ Appl Microbiol 114:1642-1649

Slim S, M Azouzi, M Salah, YB Mohamed, F Ayed, M Louhaichi (2017). Antifungal activity of essential oil from Myrtle (Myrtus communis L.). Sylwan 161:63-78

Titouhi F, M Amri, C Messaoud, S Haouel, S Youssfi, A Cherif, JMB Jemâa (2017). Protective effects of three Artemisia essential oils against Callosobruchus maculatus and Bruchus rufimanus (Coleoptera: Chrysomelidae) and the extended side-effects on their natural enemies. J Stor Prod Res 72:11-20

Tripathi AK, V Prajapati, A Ahmad, KK Aggarwal, SPS Khanuja (2004). Piperitone oxide as toxic, repellent and reproduction retardant toward malarial vector Anopheles stephensi (Diptera: Anophelinae). J Med Entomol 41:691-698

Tripathi P, NK Dubey, AK Shkula (2007). Use of some essential oils as post-harvest botanical fungicides in the management of grey mould of grapes caused by Botrytis cinerea. World J Microbiol Biotechnol 24:39-46

Vitoratos A, D Bilalis, A Karkanis, A Efthimiadou (2013). Antifungal activity of plant essential oils against Botrytis cinerea, Penicillium italicum, Penicillium digitatum. Not Bot Hortic Agrobot Cluj-Nap 41:86-92

Viuda-Martos M, E Sendra, J Pérez Alvarez, J Fernández López, M Amensour, J Abrini (2011). Identification of flavonoid content and chemical composition of the essential oils of Moroccan herbs: Myrtle (Myrtus communis L.), Rockrose (Cistus ladanifer L.) and Montpellier cistus (Cistus monspeliensis L.). J Essent Oil Res 23:1-9

Williamson B, B Tudzynski, P Tudzynski, JAV Kan, (2007). Botrytis cinerea: the cause of grey mould disease. Mol Plant Pathol 8:561-580

Yadav RS, S Kumar, A Dikshit (2006). Antifungal properties of essential oil of Mentha spicata L var. MSS-5. Ind J Crop Sci 1:197-200

Zapata N, G Smagghe (2010). Repellency and toxicity of essential oils from the leaves and bark of Laurelia sempervirens and Drimyswinteri against Tribulium castaneum. Ind Crops Prod 32:405-410

Zhang XX, SS Yan, SJ Liu, MZ Wang, YW Zhang, JY Liang (2018). Evaluation of contact and fumigant activities of essential oils distilled from Artemisia roxburghiana and Artemisia sacrorum against three stored pests. Intl J Res Pharm Biosci 5:1-5 